The Banjo 



\section{THE BANJO}

America's African Instrument

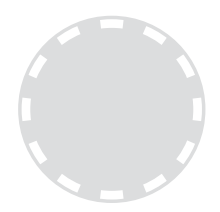

LAURENT DUBOIS

The Belknap Press of Harvard University Press

Cambridge, Massachusetts, and London, England

2016 
Copyright (C) 2016 by Laurent Dubois

ALL RIGHTS RESERVED

Printed in the United States of America

\section{First printing}

Library of Congress Cataloging-in-Publication Data

Dubois, Laurent, 1971- author.

The banjo : America's African instrument / Laurent Dubois.

pages $\mathrm{cm}$

Includes bibliographical references and index.

ISBN 978-0-674-04784-6 (alk. paper)

1. Banjo-History. 2. Banjo music-History and criticism. 3. African

Americans-Music-History and criticism. 4. Music-Social aspects-United

States. 5. Music-United States-History and criticism. I. Title.

ML1015.B3D83 2016

$787.8^{\prime} 81909-\mathrm{dc} 23$ 
For Anton 
